\title{
Effects of Forest Postharvest Management Practices on Enzyme Activities in Decomposing Litter
}

\author{
M. P. Waldrop,* J. G. McColl, and R. F. Powers
}

\begin{abstract}
Forest harvesting and site preparation alter many features of the soil environment affecting biological activity and litter decomposition. One aspect of biological activity, "lignocellulase" enzyme activity, has been found to be a good predictor of litter mass loss. We determined the effects of postharvest treatments (SLASH, BROADCAST BURN, and CHIP AND PILE treatments with the intact FOREST treatment as a control) on lignocellulose degrading and nutrient releasing enzyme activities ( $\beta$-glucosidase, cellobiohydrolase, $\beta$-xylosidase, $\mathrm{N}$-acetyl-glucosaminidase, phenol oxidase, and phosphatase) in decomposing pine litter in litterbags and in the forest floor and compared them with patterns of decomposition. In the forest floor, the SLASH treatment decreased phenol oxidase and phosphatase activities by half; the CHIP AND PILE treatment decreased $\beta$-glucosidase, cellobiohydrolase, phenol oxidase, and phosphatase activities by 50 to $75 \%$; and the BROADCAST BURN treatment decreased $\mathrm{N}$-acetylglucosaminidase, phenol oxidase, and phosphatase activities by 30 to $60 \%$. In the litterbag litter, phenol oxidase activity, $\mathrm{N}$-acetyl-glucosaminidase activity, and mass loss were lower in the BROADCAST BURN treatment than in the FOREST treatment. SLASH and CHIP AND PILE treatments did not affect enzyme activities or decomposition of the litterbag litter. The relationship between enzyme activities and incremental mass loss was significant in the FOREST and CHIP AND PILE treatments for $\beta$-glucosidase, cellobiohydrolase, and $\mathrm{N}$-acetyl-glucosaminidase enzymes $(r>0.50, p<0.05)$, but not significant in the BROADCAST BURN and SLASH treatments. Although reduced enzyme activities were accompanied by lower decomposition rates, enzyme activities were not always a dominant control of decomposition in certain highly disturbed treatments.
\end{abstract}

ITter DeComposition is important for forest health because it provides nutrients for plant growth, forms soil organic matter (SOM), and improves water relations (Oades, 1988; Sollins et al., 1996). Litter decomposition results from the activity of microbial extracellular enzymes that degrade the cellulose ( $\beta$-glucosidase and cellobiohydrolase), hemicellulose (xylosidase), and lignin (phenol oxidase) fractions of litter. Enzyme activities in litter and wood are good predictors of litter decomposition and may be a limiting step in litter decomposition in some systems (Sinsabaugh et al., 1992). However, the relationship between enzyme activity and decomposition has not been examined in disturbed forest systems.

M.P. Waldrop and J.G. McColl, Dep. of Environmental Science, Policy, and Management, Univ. of California, 151 Hilgard Hall, Berkeley, CA 94720; R.F. Powers, USDA-FS, Pacific Southwest Research Station, 2400 Washington Ave, Redding, CA 96001; M.P. Waldrop, Current address: School of Natural Resources and Environment, Univ. of Michigan, 430 E. University Ave, Ann Arbor, MI 48109. Received 20 June 2002. *Corresponding author (mwaldrop@umich.edu).

Published in Soil Sci. Soc. Am. J. 67:1250-1256 (2003).
Disturbance may lead to fundamental changes in the structure and function of microbial communities (Balser et al., 2001; Schimel and Gulledge, 1998). Forest harvesting and site preparation practices often disrupt organic and mineral surface horizons, remove wood and slash, increase soil water content, temperature, and light intensity at the soil surface, cause a loss of nutrients through volatilization, leaching, and surface erosion, and alter microbial community composition and decomposition rates (Johnson 1992; Poff 1996; Marshall, 2000). Concomitant changes in microbial community characteristics are not necessarily predictable, however. Busse et al. (2002) found that resilience of microbial communities in the surface soil (size, activity, and composition) in a 5- to 10 -yr period after harvest varied by regional climate and the type of associated disturbance. Postharvest control of competing vegetation (weeds) generally was more detrimental to microbial characteristics than either severe soil compaction or complete removal of surface organic matter.

We examined the biotic and abiotic characteristics of the forest floor and litterbag litter of a mature forest and three postharvest treatments. Our objectives were to quantify the effects of postharvest practices on decomposition and enzyme activities in the forest floor and litterbag litter, to relate enzyme activities to litter mass loss, and to determine whether alterations in litter decomposition rates could be explained by the patterns of enzymatic activity. We hypothesized that postharvest practices would decrease decomposition rates by decreasing the enzymatic potential of the microbial community.

\section{MATERIALS AND METHODS}

\section{Experimental Site}

The experimental site lies on the western slope of the Sierra Nevadas (elevation $1280 \mathrm{~m}$ ) near Georgetown, CA $\left(120^{\circ} 39^{\prime}\right.$ W long., 38 53' N lat.), on Sierra Pacific Industries' property. The climate is Mediterranean with warm dry summers and cool wet winters. Mean air temperature for our 15-mo study (1996-1997) was $11^{\circ} \mathrm{C}$ and ranged from $22.2^{\circ} \mathrm{C}$ in July to $4.3^{\circ} \mathrm{C}$ in January. Precipitation was $259 \mathrm{~cm}$ over our study period, with no precipitation in July and a maximum $63 \mathrm{~cm}$ in December. Soil drought normally begins in July and extends through September. The soil is the Cohasset series (fine-loamy, mixed, mesic Ultic Haploxeralfs) formed from basalt. This soil is typical of much of the productive forest zone within the region of volcanic rocks and is very low in plant available-P (Powers et al., 1978).

The soil supports an even-aged, 80-yr-old, closed canopy,

Abbreviations: O.D., optical density; pNP, para-nitrophenol; SOM, soil organic matter. 
mixed-conifer forest (FOREST treatment). The main tree species were, in order of decreasing abundance, ponderosa pine (Pinus ponderosa Dougl. ex Laws), incense-cedar (Libocedrus decurrens, Torr.), white fir (Abies concolor (Gord. \& Glend.) Hilderb.), Douglas-fir (Pseudotsuga menziesii (Mirb.) Franco), sugar pine (Pinus lambertiana Dougl.), and tanoak (Lithocarpus densiflorus (Hook \& Arn.) Rehd.). Standing biomass at harvest averaged $353 \mathrm{Mg} \mathrm{ha}^{-1}$, of which $87 \%$ was in bole wood, and $13 \%$ was in branches and foliage (Powers, 2002, In review). Three $25-\mathrm{m}^{2}$ plots, separated by approximately $300 \mathrm{~m}$, were randomly selected from within the mature forest (termed the 'FOREST' treatment).

\section{Postharvest Treatments}

In addition to the FOREST treatment, there were three postharvest treatments titled CHIP AND PILE, SLASH, and BROADCAST BURN. After a portion of the forest was clearcut in July 1993, all logging slash (crowns and woody stems $<15 \mathrm{~cm}$ in diameter), understory vegetation $(0.2 \mathrm{Mg}$ $\left.\mathrm{ha}^{-1}\right)$, and forest floor material $\left(78.7 \mathrm{Mg} \mathrm{ha}^{-1}\right)$ were retained on the site and randomly subdivided into several 0.21 -ha treatment plots. Treatment plots were located approximately 200 to $500 \mathrm{~m}$ from one another. Three plots were randomly assigned the CHIP AND PILE treatment where all logging slash was retained, and stems and branches larger than $2.5 \mathrm{~cm}$ in diameter in the slash were mechanically chipped and piled into windrows. SLASH treatment plots were created between CHIP AND PILE treatment windrows where slash and litter was covering the mineral soil. In the three BROADCAST BURN treatment plots, all logging slash and litter were retained and broadcast burned in a low-intensity fire in April 1994.

\section{Litterbags}

Litterbags were made from 5- and 1-mm nylon mesh material for the top and bottom, respectively, to allow macrofauna to enter the litterbags but minimize loss of small fragments of litter. Pine litter was previously collected from the forest floor in six sites of a mature stand of pure ponderosa at the USDA Forest Service Institute of Forest Genetics in Placerville, CA, $19 \mathrm{~km}$ south. Pine needle litter ( $<1 \mathrm{yr}$ old $)$ was collected, air dried, and placed into litterbags. Each litterbag contained $9.43 \mathrm{~g}$ of oven-dry weight (10.0 g air dry wt) pine litter. The pine litter contained $457 \mathrm{~g} \mathrm{~kg}^{-1} \mathrm{C}, 6.8 \mathrm{~g} \mathrm{~kg}^{-1} \mathrm{~N}$, $0.26 \mathrm{mg} \mathrm{g}^{-1} \mathrm{P}, 2.36 \mathrm{mg} \mathrm{g}^{-1} \mathrm{Ca}$, and $0.04 \mathrm{mg} \mathrm{g}^{-1} \mathrm{~K}$.

Litterbags were placed in the field in February 1996. Five litterbags were placed into each plot (three plots per treatment). In the FOREST, BROADCAST BURN, and SLASH treatment plots, the litterbags were placed underneath litter material, just above the mineral soil. In the CHIP AND PILE treatment, litterbags were placed within the windrow, approximately $15 \mathrm{~cm}$ deep, but still above the mineral soil. One litterbag was collected from each treatment plot every 3 mo for 15 mo (May, August, November, and February and May of the following year) corresponding 70, 154, 238, 345, and $429 \mathrm{~d}$ after placement. After retrieval, the litterbags were placed into plastic bags and kept at $4^{\circ} \mathrm{C}$ until analyzed. In the lab, litterbag litter was gently shaken by hand to remove soil particles, weighed, and cut into $1-\mathrm{cm}$ segments. One subsample was dried $\left(65^{\circ} \mathrm{C}\right.$ for $\left.24 \mathrm{~h}\right)$, weighed, ashed, and weighed again to quantify moisture content and mass loss. Litterbag litter was also subsampled for enzyme and nutrient analysis.

\section{Forest Floor}

"Forest floor" will be used to describe the non-litterbag litter present in each treatment from the surface to the bottom of the $\mathrm{O}$ horizon. Forest floor enzyme activities and nutrient concentrations were determined on samples collected by hand at a minimum of two points adjacent to litterbags (approx. $40 \mathrm{~g}$ of litter). Forest floor litter was collected on all dates as the litterbag litter except May 1996. Although mass loss of the forest floor was not measured directly, we estimated forest floor mass loss using a model based on a simple linear regression between enzyme activity and mass loss in the litterbags. This assumes that enzyme activity is related to litter mass loss in the same way for multiple litter types. During the summer months (June-August), temperature data $\left({ }^{\circ} \mathrm{C}\right)$ of the forest floor was measured 30 times daily at the same depth as the litterbags using a data logger (HOBO, Onset Computer Corp., Bourne, MA).

\section{Enzyme Activity Determination}

Enzyme activity was determined within $48 \mathrm{~h}$ of collection. Approximately a 5-g (wet wt) subsample of litter fragments was suspended in $150 \mathrm{~mL}$ of acetate buffer (50 mM, pH 5.0), and homogenized in a 200-mL blender for $45 \mathrm{~s}$. Each homogenate was assayed for $\beta$-1,4-glucosidase (EC 3.2.1.21), cellobiohydrolase (EC 3.2.1.91), $\beta$-xylosidase (EC 3.2.1.37), $\beta$-N-acetylglucosaminidase (EC 3.2.1.30), phenol oxidase (EC 1.10.3.2), and acid phosphomonoesterase (EC 3.1.3.2). All enzyme assays except phenol oxidase utilized $p$-nitrophenol (pNP)-linked enzyme substrates. There were four analytical replicates and duplicate controls of each homogenate assay. All assays were conducted in a constant temperature room at $20^{\circ} \mathrm{C}$ and therefore were not actual field rates of activity. Instead, they indicate aggregated enzyme potentials. Enzyme activities were expressed as micromole of substrate converted per hour per gram of dry litter ( $\mu$ mol substrate converted $\mathrm{h}^{-1} \mathrm{~g}^{-1}$ dry litter). Enzyme activities were not determined on litter before being placed in the field.

Two milliliter of homogenate was mixed with $2 \mathrm{~mL}$ of $50 \mathrm{~m} M$ pNP substrate solution and reacted for 1 to $3 \mathrm{~h}$ on a shaker except for $\mathrm{pNP}$-cellobioside and $\mathrm{pNP}-\beta$-N-acetylglucosaminide that used $2 \mathrm{~m} M$ substrate concentrations. The reaction was terminated by addition of $0.2 \mathrm{~mL}$ of $1.0 \mathrm{M} \mathrm{NaOH}$. Solution volume was brought to $10 \mathrm{~mL}$ and optical density (O.D.) measured at $410 \mathrm{~nm}$ in a spectrophotometer. Controls for homogenate and substrate color were also conducted (Sinsabaugh et al., 1992). Phenol oxidase activity was determined by mixing $2 \mathrm{~mL}$ of extract with $2 \mathrm{~mL}$ of $10 \mathrm{mM}$ L-dihydroxyphenyalanine (DOPA), prepared in $50 \mathrm{~m} M$ acetate buffer, in a cuvette. Buffer-diluted extract was used as the control. After $1 \mathrm{~h}$ of incubation, sample O.D. was measured at $460 \mathrm{~nm}$. Oxidized L-DOPA was used as a standard.

\section{Nutrient Determination}

Total $\mathrm{C}$ and $\mathrm{N}$ were determined using a $\mathrm{C} / \mathrm{N}$ analyzer (Carlo-Erba, Milan, Italy). Total P, Ca, and $\mathrm{K}$ were determined using an Inductively Coupled Plasma Spectrophotometer (ILOG) after nitric acid digestion. Organic $\mathrm{P}$ was measured using the molybdate-blue method after sulfuric acid digestion (Page et al., 1982).

\section{Statistics}

Simple linear regressions were performed, relating percentage of mass loss per 3-mo interval to individual enzyme activities. Analysis of Variance and Tukey-Kramer HSD tests were performed using Statistix Software (Analytical Software, Tallahassee, FL) to test differences among treatment means $(p=$ $0.05)$. Tukey-Kramer HSD tests were only performed if the overall ANOVA showed significance at $p<0.05$. Correlation 
Table 1. Description of forest floor depth, temperature, and nutrient concentrations in the forest and three postharvest treatments.

\begin{tabular}{|c|c|c|c|c|c|c|c|c|}
\hline Treatment & Depth $\dagger$ & Temperature $\ddagger$ & $\mathbf{N} \S$ & $\mathrm{C} \S$ & Total P§ & Organic P§ & $\mathrm{Ca} \S$ & $\mathbf{K} \S$ \\
\hline & cm & ${ }^{\circ} \mathbf{C}$ & \multicolumn{2}{|c|}{$-\mathrm{g} \mathrm{kg}^{-1}-$} & & - mg g & & \\
\hline FOREST & $12^{\mathrm{b}} \mathrm{I}$ & $16.2^{\mathrm{b}}$ & $12^{\mathrm{a}}$ & $390^{\mathrm{a}}$ & $0.44^{b}$ & $0.20^{\mathrm{a}}$ & $10.1^{\mathrm{a}}$ & $0.62^{\mathrm{a}}$ \\
\hline SLASH & $5 c^{11}$ & $20.1^{c}$ & $1^{\mathrm{a}}$ & $370^{\mathrm{a}}$ & $0.46^{b}$ & $0.14^{b}$ & $6.9^{b}$ & $0.24^{b}$ \\
\hline CHIP AND PILE & $20^{\mathrm{a}}$ & $14.1^{\mathrm{a}}$ & $7^{b}$ & $420^{\mathrm{a}}$ & $0.11^{c}$ & $\mathbf{0 . 0 8}^{\mathrm{c}}$ & $1.7^{\mathrm{c}}$ & $0.12^{\mathrm{c}}$ \\
\hline BROADCAST BURN & $\mathbf{1}^{\mathrm{d}}$ & $20.2^{\mathrm{c}}$ & $12^{\mathrm{a}}$ & $390^{\mathrm{a}}$ & $0.67^{a}$ & $0.15^{\text {ab }}$ & $10.9^{\mathrm{a}}$ & $0.32^{b}$ \\
\hline
\end{tabular}

$\dagger$ Depth of litter was measured at the beginning of the study $(n=3)$.

† Temperature data were recorded 30 times daily at bottom of $O$ horizon from June to August.

$\S$ All nutrient concentrations are mean annual values ( $n=12$ per treatment; 3 plots $\times 4$ dates).

II Letter superscripts indicate differences among column means $(p<0.05)$.

analyses were performed using JMP software (SAS Institute Inc., Cary, NC).

\section{RESULTS}

\section{Temperature and Moisture}

Forest harvesting (SLASH treatment) decreased the depth of the litter layer, lowered forest floor moisture content and increased forest floor summer temperature compared with the FOREST treatment. Burning of the slash did not alter litter temperature or moisture more than the SLASH treatment (Tables 1 and 2). On the other hand, the CHIP AND PILE treatment was deeper and cooler than the FOREST, yet had similar moisture content. The moisture contents of the forest floor and litterbag litter were highly variable seasonally. Forest floor moisture content across all treatments was lowest in August $\left(70 \mathrm{~g} \mathrm{~kg}^{-1}\right)$, highest in February $\left(1700 \mathrm{~g} \mathrm{~kg}^{-1}\right)$ and intermediate in November and May (670 and $960 \mathrm{~g}$ $\mathrm{kg}^{-1}$, respectively). Litterbag litter moisture was very high at the first sampling date in May (2798 $\mathrm{g} \mathrm{kg}^{-1}$ ), lowest in August (151 $\left.\mathrm{g} \mathrm{kg}^{-1}\right)$, and intermediate in November, February, and May of the second year (448, 712 , and $388 \mathrm{~g} \mathrm{~kg}^{-1}$, respectively). In contrast to the forest floor, there were no differences in litterbag litter moisture contents among treatments (Table 2). Disregarding the first May sampling date for which there is no forest floor data, litterbag litter moisture content was always lower than forest floor litter moisture (Table 2).

\section{Nutrient Concentration}

Forest floor nutrient concentration was affected differently by the postharvest treatments. Although the
SLASH and the BROADCAST BURN treatments did not differ in forest floor $\mathrm{C}$ or $\mathrm{N}$ concentrations compared with the FOREST treatment, the SLASH treatment had lower organic $\mathrm{P}, \mathrm{Ca}$, and $\mathrm{K}$ and the BROADCAST BURN treatment had higher total $\mathrm{P}$ and lower $\mathrm{K}$ concentrations (Table 1). The CHIP AND PILE treatment had a lower total $\mathrm{N}$, total $\mathrm{P}$, organic $\mathrm{P}, \mathrm{Ca}$, and $\mathrm{K}$ concentrations than the FOREST treatment and the SLASH and BROADCAST BURN treatments (Table 1).

The litterbag litter $\mathrm{P}$ concentration did not decrease over time, except in the CHIP AND PILE treatment where total $\mathrm{P}$ was lower than the FOREST treatment $\left(0.27 \pm 0.03 \mathrm{mg} \mathrm{g}^{-1}\right.$ and $0.33 \pm 0.02 \mathrm{mg} \mathrm{g}^{-1}$, respectively). $\mathrm{N}$ was initially immobilized and then released, but there were no treatment effects. $\mathrm{N}$ concentration was $6.8 \pm$ $0.2 \mathrm{mg} \mathrm{kg}^{-1}$ in the original litter, increased to $8.6 \pm$ $0.5 \mathrm{mg} \mathrm{kg}^{-1}$ at $3 \mathrm{mo}$, and then decreased to $5.5 \pm 0.3 \mathrm{mg}$ $\mathrm{kg}^{-1}$ at Month 15 .

\section{Enzyme Activities}

Forest floor enzyme activities (except xylosidase) were generally lower in the postharvest treatments compared with the FOREST. All three postharvest treatments had significantly lower phenol oxidase and phosphatase activities compared with the FOREST treatment (down 48 to $75 \%$ and 52 to $66 \%$, respectively). Additionally, the CHIP AND PILE treatment had lower $\beta$-glucosidase (down 60\%) and cellobiohydrolase activity (down 71\%) and the BROADCAST BURN treatment had lower NAGase (down 30\%) activity compared with litter in the mature forest (Table 2). These differences may arise from a combination of differences in substrate quality as well as microbial physiol-

Table 2. Enzyme activities, moisture content, and mass loss in litterbag litter and forest floor.

\begin{tabular}{|c|c|c|c|c|c|c|c|c|}
\hline $\begin{array}{l}\text { Enzymes and } \\
\text { litter properties }\end{array}$ & FOREST & SLASH & $\begin{array}{l}\text { terbag li } \\
\text { CHIP } \\
\text { AND } \\
\text { PILE }\end{array}$ & BROADCAST BURN & FOREST & SLASH & $\begin{array}{c}\text { Forest floor } \\
\text { CHIP } \\
\text { AND } \\
\text { PILE }\end{array}$ & BROADCAST BURN \\
\hline & & & & $\mu n$ & $\mathrm{~g}^{-1}$ & & & \\
\hline$\beta$-glucosidase & $12.9^{\mathrm{a}} \dagger$ & $14.1^{\mathrm{a}}$ & $15.3^{\mathrm{a}}$ & $15.3^{\mathrm{a}}$ & $8.7^{x}$ & $7.6^{x}$ & $3.5^{y}$ & $8.1^{x}$ \\
\hline Cellobiohydrolase & $3.6^{\mathrm{a}}$ & $4.0^{\mathrm{a}}$ & $4.2^{\mathrm{a}}$ & $4.6^{\mathrm{a}}$ & $1.4^{x}$ & $1.3^{x}$ & $0.4^{y}$ & $1.3^{x}$ \\
\hline NAGase & $8.0^{\mathrm{a}}$ & $7.0^{\mathrm{a}}$ & $8.5^{\mathrm{a}}$ & $5.8^{b}$ & $3.4^{\mathrm{x}}$ & $2.5^{x}$ & $2.1^{x}$ & $2.4^{y}$ \\
\hline Xylosidase & $1.7^{\mathrm{a}}$ & $2.2^{\mathrm{a}}$ & $1.4^{\mathrm{a}}$ & $1.8^{\mathrm{a}}$ & $0.3^{\mathrm{x}}$ & $0.4^{x}$ & $0.2^{x}$ & $0.5^{x}$ \\
\hline Phenol oxidase & $2.9^{\mathrm{a}}$ & $2.0^{\mathrm{a}}$ & $1.9^{\mathrm{a}}$ & $1.2^{\mathrm{b}}$ & $5.6^{x}$ & $2.1^{y}$ & $1.4^{y}$ & $2.9^{y}$ \\
\hline Phosphatase & $21.6^{\text {ab }}$ & $20.6^{\text {ab }}$ & $22.6^{\mathrm{a}}$ & $18.3^{\mathrm{b}}$ & $17.0^{x}$ & $8.2^{y}$ & $8.0^{y}$ & $5.7^{y}$ \\
\hline Moisture content $\left(\mathrm{g} \mathrm{kg}^{-1}\right) \ddagger$ & $439^{\mathrm{a}}$ & $403^{a}$ & $544^{\mathrm{a}}$ & $314^{a}$ & $980^{x}$ & $640^{y}$ & $1170^{x}$ & $600^{y}$ \\
\hline Mass loss $(\%) \S$ & $22^{\mathrm{a}}$ & $18^{\mathrm{a}}$ & $19^{\mathrm{a}}$ & $8^{b}$ & $11^{x}$ & $10^{x}$ & $4^{y}$ & $10^{x}$ \\
\hline
\end{tabular}

$\dagger$ Data represent means for 15 mo of data for litterbag litter and 12 mo for forest floor ( $n=12$ for forest floor, $n=15$ for litterbag litter). Letter superscripts indicate differences among treatment means $(p<0.05)$.

$\$$ Moisture content of litterbag litter does not include data from the first sampling date in May, due to very wet conditions (see Results).

$\S$ Percentage of mass loss at $\mathbf{1 5}$ months. Mass loss of forest floor was estimated from relationship between $\mathrm{C}$-acquiring enzymes and mass loss obtained from litterbag litter. 


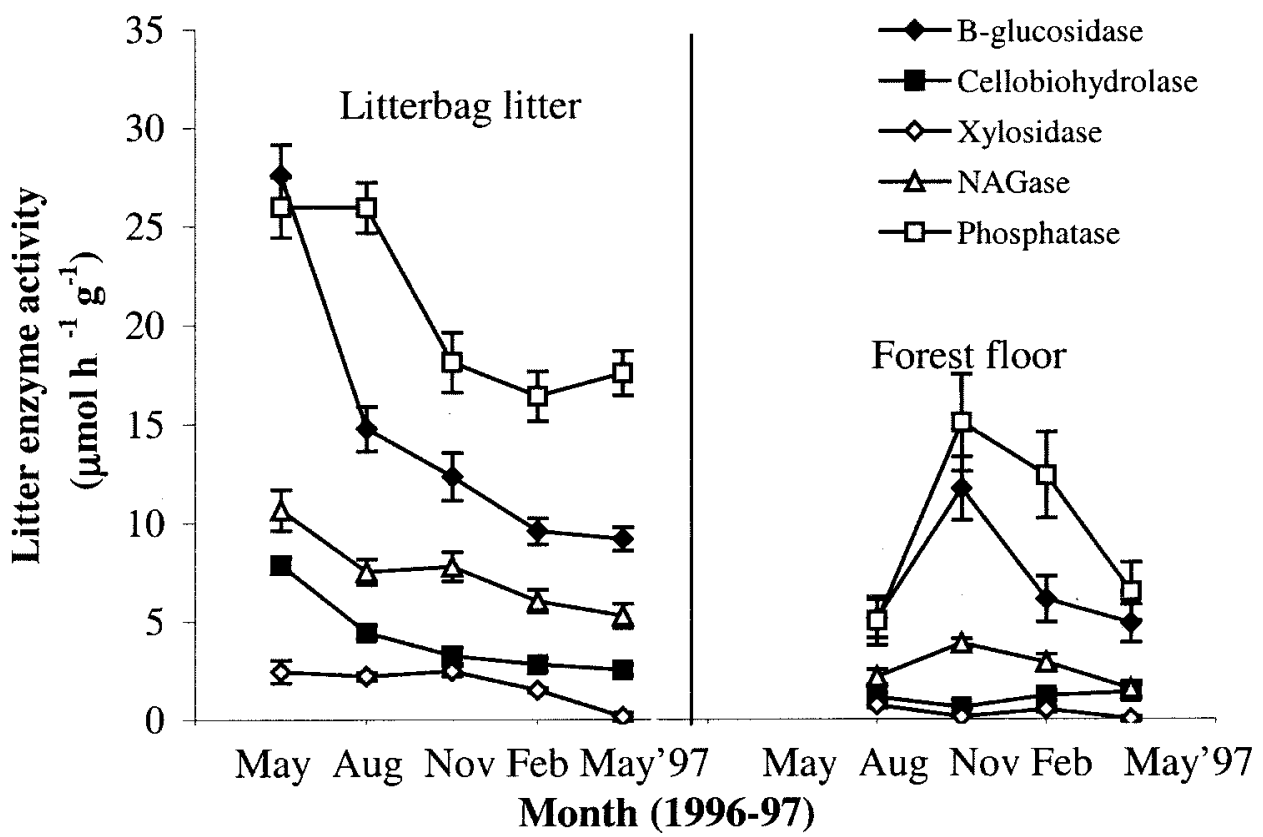

Fig. 1. Mean enzyme activities $( \pm \mathrm{SE})$ in litterbag litter and forest floor averages across all treatments over a 1-yr period $(1996-1997 ; n=12$ per collection date).

ogy, but substrate quality was not affected in the traditional sense of the $\mathrm{C} / \mathrm{N}$ ratio in the SLASH and BROADCAST BURN treatments (Table 1).

In the litterbag litter, SLASH and CHIP AND PILE treatments did not affect enzyme activities, but relative to the FOREST treatment, the BROADCAST BURN treatment decreased NAGase and phenol oxidase activity by 28 and 59\%, respectively. Our ANOVA comparing litterbag litter and forest floor enzyme activities had to disregard litterbag enzyme data from the first sampling time (May 1996) because the forest floor was not sampled. When this comparison was made, enzyme activities were always higher in litterbag litter compared with forest floor, except for phenol oxidase in the FOREST treatment, which was lower in the litterbag litter compared with forest floor (Table 2). Table 2 represents averaged data from all time points ( 5 for litterbag, 4 for forest floor), and therefore does not directly compare the forest floor and litterbag litter data.

With the exception of phenol oxidase, all enzyme activities measured in litterbag litter were highest in the first spring and decreased over the next 12 mo (Fig. 1), corresponding to both the dry season in the Mediterranean climate and the decrease in substrate quality over time. Phenol oxidase activity was temporally dissimilar from the other enzymes: its activity increased over time and did not display maximum activity in the first spring (Fig. 2). In contrast with litterbag litter, $\beta$-glucosidase, cellobiohydrolase, phenol oxidase, and phosphatase activities in the forest floor typically peaked in November and February.

\section{Relationship between Enzyme Activity and Mass Loss}

Mass loss of litterbag litter in the BROADCAST BURN treatment was only one-third that of the FOR-
EST treatment at 15 mo (Fig. 3). Mass losses values for the SLASH, and CHIP AND PILE treatments were similar to those for the FOREST (Fig. 3). Significant correlations were found between incremental mass loss (mass loss of litter per 3-mo sampling interval) and individual enzyme activities ( $\beta$-glucosidase, cellobiohydrolase, and NAGase) in the FOREST and PILE treatments (Table 3). In the SLASH and BROADCAST BURN treatments, enzyme activities were unrelated to litter mass loss. Xylosidase and phenol oxidase activities were unrelated to decomposition of litterbag litter in all treatments. Litter moisture content was also highly related to litter mass loss (Table 3 ).

In the litterbag litter, moisture content was highly correlated with $\beta$-glucosidase $(r=0.67, p<0.001)$, cellobiohydrolase $(r=0.65, p<0.001)$, NAGase $(r=$ $0.38, p<0.005)$, and phosphatase $(r=0.33, p<0.005)$ activities, but not xylosidase or phenol oxidase activity. Phosphatase was significantly negatively correlated with total $\mathrm{P}(r=-0.34, p<0.005)$, but not organic $\mathrm{P}$. In the forest floor, there was no relationship between hydrolytic enzyme activities and moisture content in the

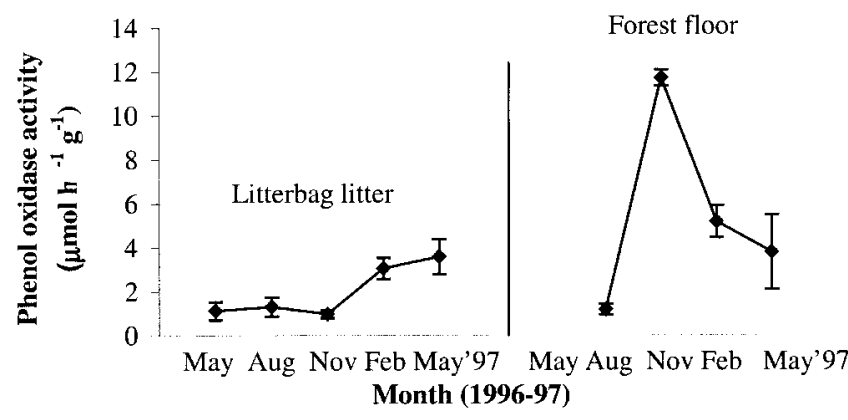

Fig. 2. Mean phenol oxidase activity of litterbag litter and forest floor $( \pm \mathrm{SE})$ averaged across all treatments over a 1-yr period (19961997; $n=12$ per collection date). 


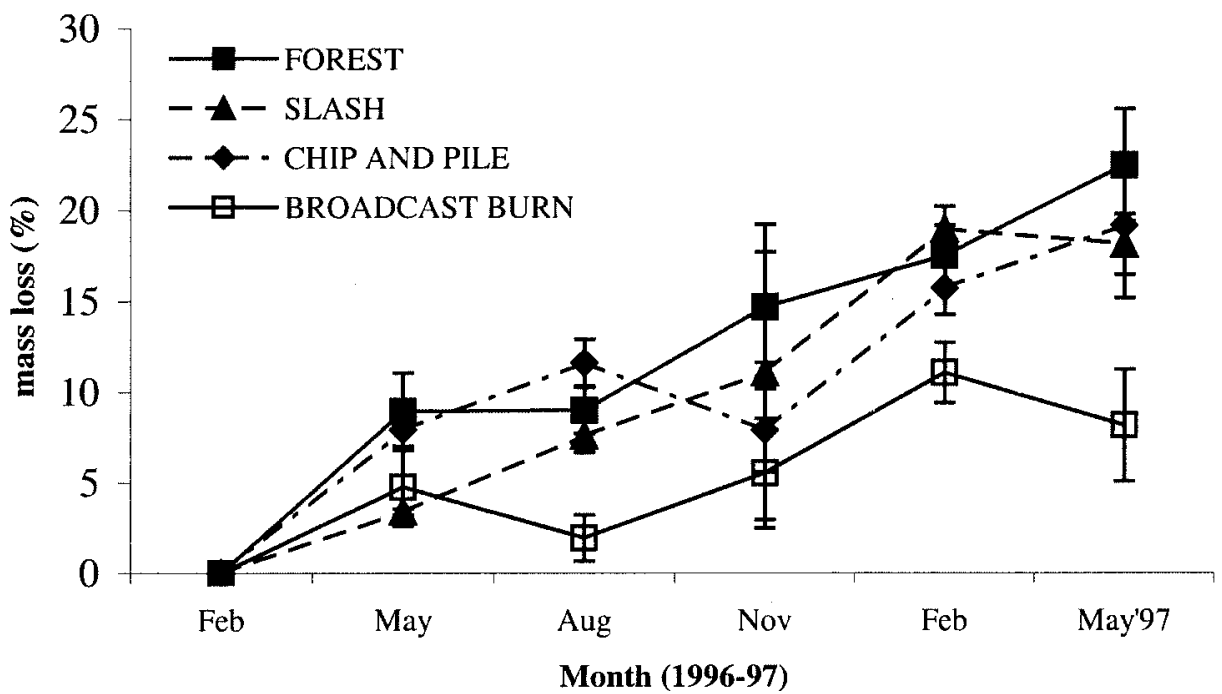

Fig. 3. Mean mass loss of litterbag litter $( \pm$ SE) in forest and postharvest treatments (1996-1997; $n=3$ per collection date).

CHIP AND PILE treatment (data not shown), but water content and total $\mathrm{P}$ were related to phenol oxidase activity $(r=0.75$ and 0.70 , respectively, $p<0.05)$. When the CHIP AND PILE treatment was excluded from the data set, moisture content was related to $\beta$-glucosidase $(r=0.39, p<0.001)$, cellobiohydrolase $(r=0.40, p<$ $0.001)$, NAGase $(r=0.54, p<0.005)$, and phosphatase activities $(r=0.68, p<0.001)$ in the other three treatments. The litter $\mathrm{C} / \mathrm{N}$ ratio was unrelated to enzyme activities in litterbag and forest floor data.

The slope of the regression between $\beta$-glucosidase enzyme activity and incremental mass loss in the litterbag litter was used to estimate the mass loss values of the forest floor in the four treatments (Sinsabaugh and Linkens, 1993). Cellobiohydrolase activity also correlated with mass loss, but it was not used because it had much lower activity than $\beta$-glucosidase (Table 2) and the variability in cellobiohydrolase activity was explained by $\beta$-glucosidase activity $(r=0.967)$. NAGase activity was also correlated with mass loss, but it is not a litter-decomposing enzyme, and therefore it was not selected to be used to predict forest floor mass loss. Percentage of mass loss of the forest floor for the 15-mo period was estimated as $\beta$-glucosidase $\times 1.26$. This estimate predicts that enzyme-based decomposition of the forest floor was $60 \%$ slower in the CHIP AND PILE treatment compared to the control FOREST. The SLASH and BROADCAST BURN treatments did not affect forest floor mass loss estimated from enzymatic activity (Table 2).

\section{DISCUSSION}

The largest effects of postharvest practices on the forest floor $3 \mathrm{yr}$ after harvesting was decreased litter layer depth and litter moisture, increased surface temperature in the SLASH and BROADCAST BURN treatments, and lower nutrient concentrations in the CHIP AND PILE treatment. The SLASH treatment forest floor had slightly lower organic $\mathrm{P}, \mathrm{Ca}$, and $\mathrm{K}$ concentrations because the planted trees were quite small and therefore there had been no new litter inputs since site preparation. However, there were no large differences in total $\mathrm{N}$ or $\mathrm{P}$ concentrations of the forest floor between the SLASH and FOREST plots. The BROADCAST BURN treatment had higher total P levels because burning typically concentrates non-volatile nutrients such as inorganic $\mathrm{P}$, but total $\mathrm{N}$, organic $\mathrm{P}$, and $\mathrm{Ca}$ concentrations were unaffected. Both the SLASH and BROADCAST BURN treatments had very shallow litter depths, which raised litter temperatures and decreased litter moisture. The CHIP AND PILE treatment, which was composed of chipped large woody debris with a high $\mathrm{C} / \mathrm{N}$ ratio, had extremely low nutrient concentrations, but temperature and moisture

Table 3. Correlation coefficients between enzyme activity in litterbag litter and temporally integrated mass loss.

\begin{tabular}{|c|c|c|c|c|c|c|c|c|}
\hline \multirow[b]{3}{*}{ Enzyme activity } & \multicolumn{6}{|c|}{$\underline{\text { Treatment }}$} & & \\
\hline & \multicolumn{2}{|c|}{ FOREST } & \multicolumn{2}{|c|}{ SLASH } & \multicolumn{2}{|c|}{ CHIP AND PILE } & \multicolumn{2}{|c|}{$\begin{array}{c}\text { BROADCAST } \\
\text { BURN }\end{array}$} \\
\hline & $r$ & $p$ & $r$ & $p$ & $r$ & $p$ & $\boldsymbol{R}$ & $p$ \\
\hline$\beta$-glucosidase & 0.57 & $*$ & 0.02 & & 0.58 & $*$ & -0.46 & \\
\hline Cellobiohydrolase & 0.49 & * & 0.03 & & 0.64 & ** & -0.45 & \\
\hline NAGase & 0.52 & * & 0.02 & & 0.58 & $*$ & -0.29 & \\
\hline Xylosidase & $-\mathbf{0 . 0 3}$ & & -0.08 & & 0.08 & & -0.15 & \\
\hline Phenol oxidase & -0.26 & & 0.01 & & -0.42 & & 0.31 & \\
\hline Moisture content & 0.57 & $*$ & 0.08 & & 0.53 & ** & -0.07 & \\
\hline
\end{tabular}

* Significant at the 0.05 probability level.

** Significant at the 0.01 probability level. 
characteristics were similar to the forest floor because of insulating properties of a thick chip pile.

Reductions in forest floor biological enzyme activities were most probably related to alterations in forest floor moisture content in the SLASH and BROADCAST BURN treatments and to reduced nutrient concentrations in the CHIP AND PILE treatment, reflecting the most dramatic alterations in forest floor characteristics. Potentially, reductions in enzyme activity may have occurred because of reduced or inactive microbial populations, low nutrient availability, and lower moisture content (Schimel and Gulledge, 1998; Sinsabaugh and Moorhead, 1994). In our study, litter moisture content had the largest overall effect on enzyme activity. This may explain the lower NAGase and phosphatase activity in the BROADCAST BURN forest floor, and the lower phosphatase activity in the SLASH treatment, but it cannot explain the lower activity in the CHIP AND PILE treatment where litter moisture was not reduced. The lower enzymatic activity of $\beta$-glucosidase, cellobiohydrolase, and phenol oxidase in the CHIP AND PILE treatment was probably because of nutrient limitation on microbial growth and activity and to summer temperatures that were significantly lower than in any other treatment (Table 1). We did not measure microbial populations, so we do not know how microbial populations may have affected enzymatic activity, although burning of forest litter typically reduces microbial biomass and activity for several years (Dumontet et al., 1996; Jha et al., 1992).

Carbon degrading enzyme activities were directly related to litterbag litter mass loss in the FOREST and CHIP AND PILE treatments where there was a thick litter layer, but not in the SLASH or BROADCAST BURN treatments where the litter was more exposed to larger temperature and moisture fluctuations and photooxidation (Schaefer et al., 1985). The relationship between enzyme activity and decomposition has been observed in other studies (Sinsabaugh et al., 1992), but only in intact forests where the effects of soil disturbance were minimal. Although all three postharvesting treatments in this experiment can be considered large disturbances, only those that severely reduced the depth of the litter layer decoupled the relationship between enzyme activity and litter mass loss. Enzyme activities in the SLASH and BROADCAST BURN litterbag litter may still represent a minimum level of degradative activity, but greater microclimatic fluctuation and photooxidation may also play an important role.

In our study, hydrolytic enzymes were correlated with litter mass loss during the first 15 mo of decay, but oxidative enzyme activity was not, supporting the idea that litter cellulose is degraded initially and more lignified components of litter are degraded later. Over the 15 -mo period in this study, $\beta$-glucosidase and cellobiohydrolase activities were two of the best single-enzyme predictors of litter mass loss. This may be because the macromolecule they degrade, cellulose, is the most abundant plant constituent. The NAGase enzyme, which degrades chitin, a fungal cell wall constituent, was also highly correlated to mass loss, and may have been indirectly correlated with litter mass loss through at least two possible mechanisms. First, NAGase may be related to the turnover of fungal cells, which may have been active on the litter. Second, cellulolytic and chitinolytic enzymes may be released en masse during decomposition. Xylosidase was unrelated to decomposition, possibly because its activity is low and is not a rate-limiting step in decomposition. Phenol oxidase was also unrelated to decomposition. This may hold for fresh litter, but as older litter that is richer in lignin is being decomposed, phenol oxidase will probably play a more important role. This is evidenced in part by the occasional negative slope of the relationship between phenol oxidase activity and mass loss (Table 3 ) and the increasing phenol oxidase activity over time (Fig. 2). Phosphatase activity was negatively correlated to total $\mathrm{P}$ in the litterbag litter, reflecting the microbial community's physiological response to nutrient limitation. The litterbag litter in the CHIP AND PILE treatment had slightly elevated phosphatase activity and the lowest $\mathrm{P}$ availability in the surrounding litter, while the BROADCAST BURN treatment had the lowest phosphatase activity and the highest $\mathrm{P}$ availability in the surrounding forest floor. This result suggests that microbial activity in the litterbag litter is affected by $\mathrm{P}$ availability in the surrounding litter and not just that in the litterbag itself.

Our hypothesis, that postharvest treatments would reduce litterbag decomposition rates by decreasing enzymatic activity, was partially supported by our data because not all postharvest treatments responded in the same way. However, within the litterbag litter, mass loss values were only lower in those treatments that had lower hydrolytic enzyme activity. The BROADCAST BURN treatment had a large negative effect on litterbag enzyme activity and decomposition while the SLASH and CHIP AND PILE treatments had little effect. Burning generally has a large effect on biological activities. Burning of slash following forest harvesting has been found to have a strong impact on decomposition rates (Monleon and Cromack, 1996), microbial activity, and biomass (Dumontet et al., 1996) potentially because of changes in litter temperature and moisture fluctuations (Monleon and Cromack, 1996), microbial community composition, and the creation of water soluble toxic compounds by fire (Fritze et al., 1994; Pietikainen and Fritze 1993). Interestingly, the reductions in NAGase and phenol oxidase activity in the litterbag litter placed in the BROADCAST BURN treatment cannot be attributed to lower litter moisture content or lower nutrient availability because litter moisture and nutrient concentration of the litterbag litter was not reduced. Furthermore, the high correlation between enzyme activity and litter moisture results from intra-annual variability, not treatment differences. In our case, the measured reduction in enzyme activities may have occurred because of an altered physiology or lowered capacity of the microbial community both inside and outside the litterbag to produce degradative enzymes. This reduction may have been caused by high summer temperatures and extreme moisture variability resulting from the weak insulating properties of a very thin forest floor (Tables 1 and 2). Additionally, microbial populations may have been severely reduced by the BROADCAST 
BURN treatment and were then slower to recolonize litter that was placed in the field.

Mass loss values of the non-litterbag forest floor were estimated with the assumption that decomposition is directly related to the activity of $\beta$-glucosidase, the most active cellulosic enzyme in the litter. We did not measure forest floor decomposition rates directly, so we do not know the accuracy of our calculated values. However, they provide a first approximation of litter decomposition using an enzyme-based approach. In the SLASH and BROADCAST BURN treatments, where enzyme activity was not correlated significantly with litter decomposition (Table 3), the calculated mass loss values may be considered a minimum value, as photooxidation or increased litter temperatures may have played a significant role. Also, as litter ages and its quality changes, a succession of enzymes may occur in which oxidative enzyme activity becomes more important in later stages of decay.

Decomposition rates of litter may increase, remain the same, or decrease within clearcuts relative to intact forests depending on the local moisture and temperature conditions and the type and intensity of postharvest treatments (Prescott, 1997; Monleon and Cromack, 1996). Reduced decomposition rates in clearcuts allow nutrients to be held longer in a potentially available form. Otherwise, rapid decomposition may lead to nutrient losses through $\mathrm{N}$ leaching or $\mathrm{P}$ immobilization in soil when nutrient availability exceeds the uptake needs of young vegetation. Based on the litterbag portion of the study we suggest that only one site preparation practice (BROADCAST BURN) may reduce decomposition rates in a dry Mediterranean climate. This would prolong the potential availability of nutrients from subsequent litter inputs until plant growth begins again. However, our data also suggest that forest floor may not decompose at a similar relative or actual rate compared with litterbag litter, thus complicating conclusions concerning the rates of litter decomposition following a particular treatment.

Postharvest practices have significant impacts on litter characteristics, nutrient availability, and soil biological activity affecting litter decomposition rates. Although SLASH and CHIP AND PILE treatments decreased enzymatic activity in the forest floor, enzyme activities and decomposition of a common litterbag litter were unaffected. In essence, the biotic potential of the microbial community was not significantly reduced. The BROADCAST BURN treatment, however, decreased both enzymatic activity in the forest floor and the litterbag litter, and this corresponded to slower litter decomposition. This suggests a slower process rate mediated by a change in microbial enzymatic potential. Microbial activity in the BROADCAST BURN treatment was most likely suppressed by high temperatures and greater variability in litter moisture after the forest floor was thinned by fire. It is therefore important to distinguish between environments in which the relationship between enzyme activity and decomposition are coupled and environments where they may be uncoupled. These distinctions may help to clarify the relative importance of biotic and abiotic controls on litter decay.

\section{ACKNOWLEDGMENTS}

We acknowledge the help of the staff of the Blodgett Forest Research Station, University of California, Berkeley, Sierra Pacific Industries, and Therese Alves, Gary Fiddler, and Bert Spear at the USDA Forest Service for their help. Thanks to B. Cade-Menum, M. Tanwar, C. Drugan, and L. Ceballos for laboratory assistance.

\section{REFERENCES}

Balser, T.C., A.P. Kinzig, and M.K. Firestone. 2001. Linking soil microbial communities and ecosystem functioning. p. 265-357. In A.P Kinzig et al. (ed.) The functional consequences of biodiversity. Princeton Univ. Press, Princeton.

Busse, M.D., S.E. Beattie, R.F. Powers, F.G. Sanchez, and A.E. Tiarks. 2002. Microbial community responses to forest soil compaction, organic residue removal, and vegetation control. In review.

Dumontet, S., H. Dinel, A. Scopa, A. Mazzatura, and A. Saracino. 1996. Post-fire soil microbial biomass and nutrient content of a pine forest soil from a dunal Mediterranean environment. Soil Biol. Biochem. 28:1467-1475.

Fritze, H., A. Smolander, T. Levula, V. Kitunen, and E. Mälkönen. 1994. Wood-ash fertilization and fire treatments in a Scots pine forest stand: effects of the organic layer, microbial biomass, and microbial activity. Biol. Fertil. Soils 17:57-63.

Jha, D.K., G.D. Sharma, and R.R. Mishra. 1992. Soil microbial population numbers and enzyme activities in relation to altitude and forest degradation. Soil Biol. Biochem. 24:761-767.

Johnson, D.W. 1992. Effects of forest management on soil carbon storage. Water Air Soil Pollut. 64:83-120.

Marshall, V.G. 2000. Impacts of forest harvesting on biological processes in northern forest soils. For. Ecol. Manage. 133:43-60.

Monleon, V.J., and K.J. Cromack. 1996. Long-term effects of prescribed underburning on litter decomposition and nutrient release in ponderosa pine stands in central Oregon. For. Ecol. Manage. $81: 143-152$.

Oades, J.M. 1988. The retention of organic matter in soils. Biogeochemistry 5:35-70.

Page, A.L., R.H. Miller, and D.R. Keeney. (ed.) 1982. Methods of soil analysis, Part 2. ASA, Madison, WI.

Pietikainen, J., and H. Fritze. 1993. Microbial biomass and activity in the humus layer following burning: Short-term effects of two different fires. Can. J. For. Res. 23:1275-1285.

Poff, R.J. 1996. Effects of silvicultural practices and wildfires on productivity of forest soils. p. 477-495. In Status of the Sierra Nevada. Vol. II. Rep. 37. Assessments and scientific basis for managment options. Final Rep. to Congress. Univ. of California: Centers for Water and Wildland Resources, Davis, CA.

Powers, R.F. 2002. LTSP: Genesis of the concept and principles behind the program. In review.

Powers, R.F., K. Isik, and P.J. Zinke. 1978. Adding phosphorus to forest soils: Storage capacity and possible risks. Bull. Environ. Contam. Toxicol. 14:254-264.

Prescott, C.E. 1997. Effects of clearcutting and alternative silvicultural systems on rates of decomposition and nitrogen mineralization in a coastal montane coniferous forest. For. Ecol. Manage. 95:253-260.

Schaefer, D.A., Y. Steinberger, and W.G. Whitford. 1985. The failure of nitrogen and lignin control of decomposition in a North American desert. Oecologia 65:382-386.

Schimel, J.P., and J. Gulledge. 1998. Microbial community structure and global trace gases. Global Change Biol. 4:745-758.

Sinsabaugh, R.L., R.K. Antibus, A.E. Linkins, C.A. Mclaugherty, L. Rayburn, D. Repert, and T. Weiland.1992. Wood decomposition over a first-order watershed: Mass loss as a function of lignocellulase activity. Soil Biol. Biochem. 24:743-749.

Sinsabaugh, R.L., and A.E. Linkins. 1993. Statistical modeling of litter decomposition from integrated cellulase activity. Ecology 74:1594 1597.

Sinsabaugh, R.L., and D.L. Moorhead. 1994. Resource allocation to extracellular enzyme production: A model for nitrogen and phosphorus control of litter decomposition. Soil Biol. Biochem. 26: 1305-1311.

Sollins, P., P. Homann, and B.A. Caldwell. 1996. Stabilization and destabilization of soil organic matter: Mechanisms and controls. Geoderma 74:65-105. 